\title{
EDITORIAL
}

\section{Modelling pathogenic mechanisms of upper airway dysfunction in the molecular age}

\author{
A.R. Schwartz, S.P. Patil, H. Schneider and P.L. Smith
}

0 bstructive sleep apnoea (OSA) is a complex disorder consisting of periods of upper airway obstruction during sleep [1], which are terminated by arousals and oxyhaemoglobin desaturations. Most adults with this disorder present in mid-life with an up to $\sim 20$-yr progressive history of loud snoring often of increasing intensity, punctuated by witnessed apnoeas and resuscitative snorts. As sleep apnoea develops, patients may begin to complain of sleep disruption and frank daytime hypersomnolence. The reasons for the development and progression of this disorder, however, are not well understood.

A combination of inherited and acquired factors may contribute to the pathogenesis of OSA $[2,3]$. A heritable predisposition to this disorder is suggested by the elevated prevalence of sleep apnoea in males compared with females and in AfricanAmerican and East Asian compared with Western populations [4-9], as well as by studies demonstrating alterations in pharyngeal anatomy between those with and without sleep apnoea [10-12]. Conversely, weight gain and age can contribute substantially to sleep apnoea prevalence, suggesting that sleep apnoea susceptibility may also be acquired $[13,14]$. The precise mechanisms for the development of upper airway dysfunction during sleep, however, are not known.

Investigators have recognised that elevations in upper airway collapsibility play a primary role in the pathogenesis of OSA [15-24]. Recent evidence also suggests that these increases are due to pharyngeal anatomic alterations and disturbances in neuromuscular control, and that both defects in upper airway structures and neuromuscular responses are required for the development of OSA [20,25]. Upper airway structural defects may develop in association with increases in body weight and age [22, 26-28], whereas aging and post-menopausal status may promote disturbances in pharyngeal neuromuscular

\section{Johns Hopkins Sleep Disorders Center, Baltimore, MD, USA.}

SUPPORT STATEMENT: This publication was supported by HL 50381, 37379, 077137 and 72126, and made possible by UL1 RR 025005 from the National Center for Research Resources (NCRR), a component of the National Institutes of Health $(\mathrm{NIH})$, and NIH Roadmap for Medical Research. Its contents are solely the responsibility of the authors and do not necessarily represent the official view of NCRR or NIH. Information on NCRR is available at www.ncrr.nih.gov Information on Reengineering the Clinical Research Enterprise can be obtained from http://nihroadmap.nih.gov/ clinicalresearch/overview-translational.asp

STATEMENT OF INTEREST: None declared.

CORRESPONDENCE: A.R. Schwartz, Johns Hopkins Sleep Disorders Center, 5501 Hopkins Bayview Circle, Baltimore, MD 21224, USA. Fax: 1 4105503374. E-mail: aschwar2@jhmi.edu control during sleep [29-37]. Thus, pathogenic effects of obesity, age and menopause on upper airway neuromechanical function can combine to increase sleep apnoea susceptibility and progression across the lifespan.

As upper airway obstruction during sleep ensues, changes in pharyngeal mucosal and muscle function can accelerate sleep apnoea progression in humans. SÉriès et al. [38] have postulated that disease progression may be related to ultrastructural alterations in pharyngeal tissues, which are characterised by the infiltration of inflammatory cells and remodelling of extracellular matrix tissue. These histopathological changes in the pharyngeal mucosa may deaden sensory receptors that might ordinarily play a critical role in the maintenance of airway patency during sleep [39-42]. Normally, these receptors respond to the markedly negative intraluminal pressures generated during periods of upper airway obstruction by activating pharyngeal dilator muscles that restore airway patency during sleep [43-46]. Mechanical and neurosensory defects related to snoring and sleep apnoea may be exacerbated by the development of epithelial thickening and submucosal oedema [47, 48], which may also degrade the contractile efficiency of pharyngeal dilator muscles [49]. Moreover, obesity and sleep apnoea are associated with excess adipose deposition in pharyngeal tissues [11, 50,51], which can produce a state of chronic mechanical overload for the pharyngeal musculature [52]. The above findings are consistent with the notion that adiposity leads to a cascade of pharyngeal ultrastructural alterations and progressive defects in upper airway neurosensory and neuromuscular control.

Limited access to human pharyngeal tissue has hampered our ability to dissect histopathological mechanisms of pharyngeal dysfunction during sleep. Human tissue specimens have been acquired from surgery (uvulopalatopharyngoplasty) [52, 53] and/or autopsy. Interpreting histopathological data from these sources is probably confounded by patient selection bias and/ or incomplete characterisation of sleep apnoea disease status. Rodent models can overcome these limitations by elucidating the molecular, cellular and histopathological disturbances that result from controlled physiological alterations in normal upper airway tissues.

In the present issue of the European Respiratory Journal, AlmENDROs et al. [54] have advanced in our understanding of sleep apnoea pathogenesis significantly by utilising an established isolated upper airway model [55-62]. By modelling the impact of repetitive airway closure and reopening on pharyngeal tissue characteristics, these investigators have demon- 


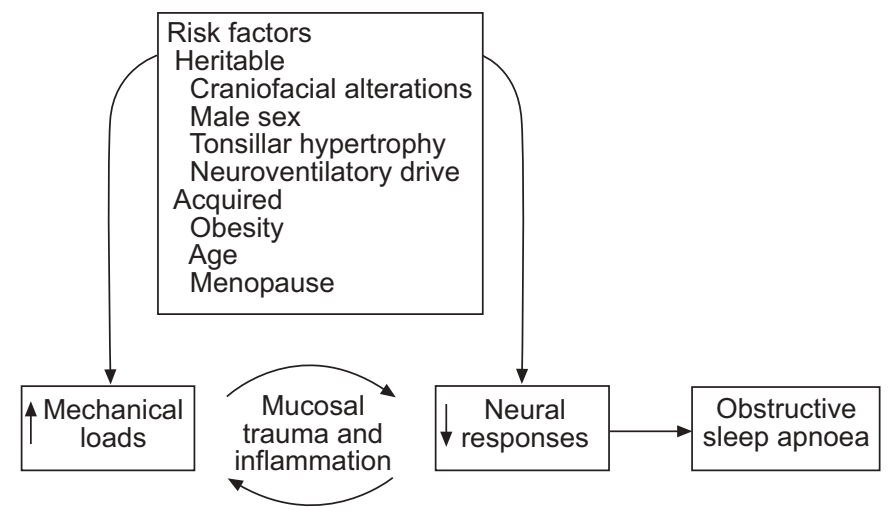

FIGURE 1. Mechanisms of upper airway dysfunction and sleep apnoea pathogenesis. Sleep apnoea risk factors are associated with defects in upper airway mechanical and/or neural control. These alterations produce collapse, vibration (snoring) or repetitive opening and closure of the pharynx (obstructive apnoea). Mechanical trauma can cause inflammation, tissue oedema, and remodelling and sensory disturbances, which further impair pharyngeal mechanics and neural responses, and accelerate the progression toward sleep apnoea.

strated early changes in the expression of inflammatory genes for macrophage inflammatory protein-2, tumour necrosis factor- $\alpha$, interleukin- $1 \beta$ and P-selectin in the pharyngeal and laryngeal mucosa. Their findings indicate that the mechanical effects of snoring and periods of upper airway obstruction trigger an inflammatory cascade that may ultimately account for the ultrastructural changes in the pharyngeal mucosa, soft tissues, sensory nerves and muscles previously observed in humans [63, 64]. Inflammatory changes in the mucosa may produce sensory impairment $[65,66]$ and degrade protective reflexes to negative pressure during periods of upper airway obstruction [39-42,67]. A major implication of the findings of ALMENDROs et al. [54] in their rodent model is that a single "night" of snoring and/or obstructive apnoeas can initiate the inflammatory changes within the pharyngeal tissues. In humans, it is also possible that upper airway anatomic loads in combination with mechanical trauma can initiate a similar inflammatory process, leading to a series of ultrastructural changes that aggravate neuromechanical defects and accelerate the progression from asymptomatic snoring to OSA (fig. 1).

Some questions also remain about the impact of early changes in the expression of inflammatory genes in the laryngeal and pharyngeal mucosa. What precisely is the stimulus of gene expression changes in both the pharyngeal and laryngeal mucosa? Do these genes lead to infiltration of inflammatory cells and oedema fluid in the pharyngeal mucosa? Are these changes in gene expression responsible for chronic remodelling of the pharyngeal wall? What are the consequences of these histopathological changes on pharyngeal mechanical properties and neuromuscular responses? Is it also possible that "overspill" from pharyngeal inflammation contributes to systemic inflammation in obesity and sleep apnoea [68], and mediates the deleterious metabolic and cardiovascular effects observed in obesity and sleep apnoea [69, 70]? While numerous questions still remain, ALMENDROs et al. [54] offer a rodent upper airway model to overcome inherent limitations of human studies and elucidate underlying pharyngeal mechanisms of sleep apnoea pathogenesis.

\section{REFERENCES}

1 Remmers JE, de Groot WJ, Sauerland EK, Anch AM. Pathogenesis of upper airway occlusion during sleep. J Appl Physiol 1978; 44: 931-938.

2 Patel SR. Shared genetic risk factors for obstructive sleep apnea and obesity. J Appl Physiol 2005; 99: 1600-1606.

3 Smith PL, Gold AR, Meyers DA, Haponik EF, Bleecker ER. Weight loss in mildly to moderately obese patients with obstructive sleep apnea. Ann Intern Med 1985; 103: 850-855.

4 Ip MS, Lam B, Lauder IJ, et al. A community study of sleepdisordered breathing in middle-aged Chinese men in Hong Kong. Chest 2001; 119: 62-69.

5 Ip MS, Lam B, Tang LC, Lauder IJ, Ip TY, Lam WK. A community study of sleep-disordered breathing in middleaged Chinese women in Hong Kong: prevalence and gender differences. Chest 2004; 125: 127-134.

6 Young T, Palta M, Dempsey J, Skatrud J, Weber S, Badr S. The occurrence of sleep-disordered breathing among middle-aged adults. N Engl J Med 1993; 328: 1230-1235.

7 Redline S, Tishler PV, Hans MG, Tosteson TD, Strohl KP, Spry K. Racial differences in sleep-disordered breathing in African-Americans and Caucasians. Am J Respir Crit Care Med 1997; 155: 186-192.

8 Redline S, Tishler PV, Schluchter M, Aylor J, Clark K, Graham G. Risk factors for sleep-disordered breathing in children. Associations with obesity, race, and respiratory problems. Am J Respir Crit Care Med 1999; 159: 1527-1532.

9 Redline S, Tosteson T, Tishler PV, Carskadon MA, Millman RP, Milliman RP. Studies in the genetics of obstructive sleep apnea. Familial aggregation of symptoms associated with sleep-related breathing disturbances. Am Rev Respir Dis 1992; 145: 440-444.

10 Schwab RJ, Pasirstein M, Kaplan L, et al. Family aggregation of upper airway soft tissue structures in normal subjects and patients with sleep apnea. Am J Respir Crit Care Med 2006; 173: 453-463.

11 Schwab RJ. Genetic determinants of upper airway structure that predispose to obstructive sleep apnea. Respir Physiol Neurobiol 2005; 147: 289-298.

12 Cakirer B, Hans MG, Graham G, Aylor J, Tishler PV, Redline S. The relationship between craniofacial morphology and obstructive sleep apnea in whites and in AfricanAmericans. Am J Respir Crit Care Med 2001; 163: 947-950.

13 Newman AB, Foster G, Givelber R, Nieto FJ, Redline S, Young T. Progression and regression of sleep-disordered breathing with changes in weight: the sleep heart health study. Arch Intern Med 2005; 165: 2408-2413.

14 Peppard PE, Young T, Palta M, Dempsey J, Skatrud J. Longitudinal study of moderate weight change and sleepdisordered breathing. JAMA 2000; 284: 3015-3021.

15 Gleadhill IC, Schwartz AR, Schubert N, Wise RA, Permutt S, Smith PL. Upper airway collapsibility in snorers and in patients with obstructive hypopnea and apnea. Am Rev Respir Dis 1991; 143: 1300-1303.

16 Gold AR, Schwartz AR. The pharyngeal critical pressure. The whys and hows of using nasal continuous positive airway pressure diagnostically. Chest 1996; 110: 1077-1088.

17 King ED, O'Donnell CP, Smith PL, Schwartz AR. A model of obstructive sleep apnea in normal humans. Role of the upper airway. Am J Respir Crit Care Med 2000; 161: 1979-1984. 
18 Marcus CL, McColley SA, Carroll JL, Loughlin GM, Smith PL, Schwartz AR. Upper airway collapsibility in children with obstructive sleep apnea syndrome. J Appl Physiol 1994; 77: 918-924.

19 Oliven A, O'hearn DJ, Boudewyns A, et al. Upper airway response to electrical stimulation of the genioglossus in obstructive sleep apnea. J Appl Physiol 2003; 95: 2023-2029.

20 Patil SP, Schneider H, Marx JJ, Gladmon E, Schwartz AR, Smith PL. Neuromechanical control of upper airway patency during sleep. J Appl Physiol 2007; 102: 547-556.

21 Schwartz AR, Schubert N, Rothman W, et al. Effect of uvulopalatopharyngoplasty on upper airway collapsibility in obstructive sleep apnea. Am Rev Respir Dis 1992; 145: 527-532.

22 Schwartz AR, Gold AR, Schubert N, et al. Effect of weight loss on upper airway collapsibility in obstructive sleep apnea. Am Rev Respir Dis 1991; 144: 494-498.

23 Schwartz AR, Smith PL, Wise RA, Gold AR, Permutt S. Induction of upper airway occlusion in sleeping individuals with subatmospheric nasal pressure. J Appl Physiol 1988; 64: 535-542.

24 Winakur SJ, Smith PL, Schwartz AR. Pathophysiology and risk factors for obstructive sleep apnea. Semin Respir Crit Care Med 1998; 19: 99-112.

25 McGinley BM, Schwartz AR, Schneider H, Kirkness JP, Smith PL, Patil SP. Upper airway neuromuscular compensation during sleep is defective in obstructive sleep apnea. J Appl Physiol 2008; Epub ahead of print [PMID 18403451].

26 Schwab RJ. Pro: sleep apnea is an anatomic disorder. Am J Respir Crit Care Med 2003; 168: 270-271.

27 Schwab RJ, Gupta KB, Gefter WB, Metzger LJ, Hoffman EA, Pack AI. Upper airway and soft tissue anatomy in normal subjects and patients with sleep-disordered breathing. Significance of the lateral pharyngeal walls. Am J Respir Crit Care Med 1995; 152: 1673-1689.

28 Kirkness JP, Schwartz AR, Schneider H, et al. Contribution of male sex, age, and obesity to mechanical instability of the upper airway during sleep. J Appl Physiol 2008; 104: 1618-1624.

29 Behan M, Brownfield MS. Age-related changes in serotonin in the hypoglossal nucleus of rat: implications for sleep-disordered breathing. Neurosci Lett 1999; 267: 133-136.

30 Eikermann M, Jordan AS, Chamberlin NL, et al. The influence of aging on pharyngeal collapsibility during sleep. Chest 2007; 131: 1702-1709.

31 Hoch CC, Reynolds CF III, Monk TH, et al. Comparison of sleep-disordered breathing among healthy elderly in the seventh, eighth, and ninth decades of life. Sleep 1990; 13: 502-511.

32 Malhotra A, Huang Y, Fogel R, et al. Aging influences on pharyngeal anatomy and physiology: the predisposition to pharyngeal collapse. Am J Med 2006; 119: e9-e14.

33 Marcus CL, Fernandes do Prado LB, Lutz J, et al. Developmental changes in upper airway dynamics. J Appl Physiol 2004; 97: 98-108.

34 Oliven A, Carmi N, Coleman R, Odeh M, Silbermann M. Age-related changes in upper airway muscles morphological and oxidative properties. Exp Gerontol 2001; 36: $1673-1686$
35 Worsnop C, Kay A, Kim Y, Trinder J, Pierce R. Effect of age on sleep onset-related changes in respiratory pump and upper airway muscle function. J Appl Physiol 2000; 88: 1831-1839.

36 Fogel RB, Malhotra A, Pillar G, Pittman SD, Dunaif A, White DP. Increased prevalence of obstructive sleep apnea syndrome in obese women with polycystic ovary syndrome. J Clin Endocrinol Metab 2001; 86: 1175-1180.

37 Jordan AS, Wellman A, Edwards JK, et al. Respiratory control stability and upper airway collapsibility in men and women with obstructive sleep apnea. J Appl Physiol 2005; 99: 2020-2027.

38 Sériès F, Chakir J, Boivin D. Influence of weight and sleep apnea status on immunologic and structural features of the uvula. Am J Respir Crit Care Med 2004; 170: 1114-1119.

39 Horner RL, Innes JA, Holden HB, Guz A. Afferent pathway(s) for pharyngeal dilator reflex to negative pressure in man: a study using upper airway anaesthesia. J Physiol (Lond) 1991; 436: 31-44.

40 Horner RL, Innes JA, Murphy K, Guz A. Evidence for reflex upper airway dilator muscle activation by sudden negative airway pressure in man. J Physiol 1991; 436: 15-29.

41 Horner RL, Innes JA, Guz A. Reflex pharyngeal dilator muscle activation by stimuli of negative airway pressure in awake man. Sleep 1993; 16: Suppl. 8, S85-S86.

42 Horner RL, Innes JA, Morrell MJ, Shea SA, Guz A. The effect of sleep on reflex genioglossus muscle activation by stimuli of negative airway pressure in humans. J Physiol (Lond) 1994; 476: 141-151.

43 Malhotra A, Pillar G, Fogel RB, et al. Genioglossal but not palatal muscle activity relates closely to pharyngeal pressure. Am J Respir Crit Care Med 2000; 162: 1058-1062.

44 Malhotra A, Fogel RB, Edwards JK, Shea SA, White DP. Local mechanisms drive genioglossus activation in obstructive sleep apnea. Am J Respir Crit Care Med 2000; 161: 1746-1749.

45 Malhotra A, Pillar G, Fogel RB, et al. Pharyngeal pressure and flow effects on genioglossus activation in normal subjects. Am J Respir Crit Care Med 2002; 165: 71-77.

46 Stanchina ML, Malhotra A, Fogel RB, et al. Genioglossus muscle responsiveness to chemical and mechanical stimuli during non-rapid eye movement sleep. Am J Respir Crit Care Med 2002; 165: 945-949.

47 Hamans EP, Van Marck EA, De Backer WA, Creten W, Van de Heyning PH. Morphometric analysis of the uvula in patients with sleep-related breathing disorders. Eur Arch Otorhinolaryngol 2000; 257: 232-236.

48 Sekosan M, Zakkar M, Wenig BL, Olopade CO, Rubinstein I. Inflammation in the uvula mucosa of patients with obstructive sleep apnea. Laryngoscope 1996; 106: 1018-1020.

49 Sériès F, Cote C, St Pierre S. Dysfunctional mechanical coupling of upper airway tissues in sleep apnea syndrome. Am J Respir Crit Care Med 1999; 159: 1551-1555.

50 Ferguson KA, Ono T, Lowe AA, Ryan CF, Fleetham JA. The relationship between obesity and craniofacial structure in obstructive sleep apnea. Chest 1995; 108: 375-381.

51 Nashi N, Kang S, Barkdull GC, Lucas J, Davidson TM. Lingual fat at autopsy. Laryngoscope 2007; 117: 1467-1473.

52 Sériès F, Cote C, Simoneau JA, et al. Physiologic, metabolic, and muscle fiber type characteristics of musculus uvulae in 
sleep apnea hypopnea syndrome and in snorers. J Clin Invest 1995; 95: 20-25.

53 Sériès F, Cote $C$, Simoneau JA, St Marc I. Upper airway collapsibility, and contractile and metabolic characteristics of musculus uvulae. FASEB J 1996; 10: 897-904.

54 Almendros I, Carreras A, Ramírez J, Montserrat JM, Navajas D, Farré R. Upper airway collapse and reopening induce inflammation in a sleep apnoea model. Eur Respir J 2008; 32: 399-404.

55 McWhorter AJ, Rowley JA, Eisele DW, Smith PL, Schwartz AR. The effect of tensor veli palatini stimulation on upper airway patency. Arch Otolaryngol Head Neck Surg 1999; 125: 937-940.

56 Rowley JA, Permutt S, Willey S, Smith PL, Schwartz AR. Effect of tracheal and tongue displacement on upper airway airflow dynamics. J Appl Physiol 1996; 80: 2171-2178.

57 Rowley JA, Williams BC, Smith PL, Schwartz AR. Neuromuscular activity and upper airway collapsibility. Mechanisms of action in the decerebrate cat. Am J Respir Crit Care Med 1997; 156: 515-521.

58 Schwartz AR, Thut DC, Russ B, et al. Effect of electrical stimulation of the hypoglossal nerve on airflow mechanics in the isolated upper airway. Am Rev Respir Dis 1993; 147: 1144-1150.

59 Schwartz AR, Thut DC, Brower RG, et al. Modulation of maximal inspiratory airflow by neuromuscular activity: effect of $\mathrm{CO}_{2}$. J Appl Physiol 1993; 74: 1597-1605.

60 Seelagy MM, Schwartz AR, Russ DB, King ED, Wise RA, Smith PL. Reflex modulation of airflow dynamics through the upper airway. J Appl Physiol 1994; 76: 2692-2700.

61 Nakano H, Magalang UJ, Lee SD, Krasney JA, Farkas GA. Serotonergic modulation of ventilation and upper airway stability in obese Zucker rats. Am J Respir Crit Care Med 2001; 163: 1191-1197.
62 Ogasa T, Ray AD, Michlin CP, Farkas GA, Grant BJ, Magalang UJ. Systemic administration of serotonin 2A/2C agonist improves upper airway stability in Zucker rats. $A m$ J Respir Crit Care Med 2004; 170: 804-810.

63 Boyd JH, Petrof BJ, Hamid Q, Fraser R, Kimoff RJ. Upper airway muscle inflammation and denervation changes in obstructive sleep apnea. Am J Respir Crit Care Med 2004; 170: 541-546.

64 Petrof BJ, Pack AI, Kelly AM, Eby J, Hendricks JC. Pharyngeal myopathy of loaded upper airway in dogs with sleep apnea. J Appl Physiol 1994; 76: 1746-1752.

65 Nguyen AT, Jobin V, Payne R, Beauregard J, Naor N, Kimoff RJ. Laryngeal and velopharyngeal sensory impairment in obstructive sleep apnea. Sleep 2005; 28: 585-593.

66 Kimoff RJ, Sforza E, Champagne V, Ofiara L, Gendron D. Upper airway sensation in snoring and obstructive sleep apnea. Am J Respir Crit Care Med 2001; 164: 250-255.

67 Cala SJ, Sliwinski P, Cosio MG, Kimoff RJ. Effect of topical upper airway anesthesia on apnea duration through the night in obstructive sleep apnea. J Appl Physiol 1996; 81: 2618-2626.

68 Punjabi NM, Beamer BA. C-reactive protein is associated with sleep disordered breathing independent of adiposity. Sleep 2007; 30: 29-34.

69 Nieto FJ, Young TB, Lind BK, et al. Association of sleepdisordered breathing, sleep apnea, and hypertension in a large community-based study. Sleep Heart Health Study. JAMA 2000; 283: 1829-1836.

70 Shahar E, Whitney CW, Redline S, et al. Sleep-disordered breathing and cardiovascular disease: cross-sectional results of the Sleep Heart Health Study. Am J Respir Crit Care Med 2001; 163: 19-25. 